\title{
The Effect of Using SMS as a Post Task Activity on Iranian EFL Learners' Grammar Knowledge
}

\author{
Mohamad Reza Farangi \\ Shiraz University, Shiraz, Iran \\ Jamileh Kamyab \\ Islamic Azad University, Torbat-e-Heydariyeh Branch, Iran \\ Majid Izanlu \\ Kharazmi University, Tehran, Iran \\ Nazanin Ghodrat \\ Kharazmi University, Tehran, Iran
}

\begin{abstract}
The current study aimed at investigating the effect of using SMS on Iranian upper-intermediate EFL learners' grammar learning. Moreover, the effect of using SMS on the Iranian EFL students' autonomy and their perception of it as an educational tool was investigated. The participants of the present study consisted of 60 upper-intermediate Iranian EFL learners. Different instrumentations including the Oxford Placement Test (OPT), grammar test, and Autonomy Questionnaire were used in this study. Through adopting a quasi-experimental design with a pretest- treatment-posttest sequence, participants were divided into Experimental and Control group. The data was analyzed and inferentially compared using independent sample and paired sample t-test. The results indicated that there was a statistically significant difference between the pretest and posttest means of experimental and control group regarding their performance in grammar test. The results showed that experimental group learners outperformed the learners in control group. Therefore, using SMS had a significant effect on Iranian EFL learners' effective learning of grammatical structures; in addition, it helped students to increase their autonomy towards learning. As an implication of this study, it is proposed that SMS usage can be incorporated into language classroom effectively to enhance learners' learning of different language skills.
\end{abstract}

Index Terms - SMS, grammar learning, EFL learners, autonomy

\section{INTRODUCTION}

In today's world in which technology and science are quickly expanding, distance communication through wireless technology is not very surprising. Since mobile phones with a variety of usages creep into all dimensions of our lives, it is expected that this multipurpose device will soon turn into an indispensable part of our everyday life. Then, widespread access this fashionable device with competitive prices has almost revolutionized e-learning in many different ways. According to Prensky (2005), among the important technologies available for the students in the language classroom, mobile phone plays a very important role. They are user-friendly devices with lots of applications helpful for the process of learning a foreign language. O'Malley et al. (2003) consider mobile learning as the learning that is not in a fixed state and can take place at any time and in any place, and so extends language learning outside the walls of the classroom. Klopfer et al. (2002) identified the following properties of mobile learning: 1) connectivity: it's possible to connect mobile devices to each other or to connect them to an established network, 2) social interactivity: mobile phones enable us to exchange data and collaborate with other learners, 3) context sensitivity: the data on the mobile devices can be collected and replied exclusively to the existing location and time, 4) portability: mobile phone are easily handled and are available anywhere and anytime, and 5) individuality: mobile phones can be easily customized for a particular person. Using mobile phones in the language classroom introduced a new concept in teaching languages that is Mobile Assisted Language Learning (MALL). Over the past decade, MALL has developed into a sophisticated field within its own right and a large number of articles have examined different mobile devices within various environments. Kukulska-Hulme (2013, p. 3701) defines MALL as the use of "mobile technologies in language learning, especially in situations where device portability offers specific advantages". According to him, Mobile learning consists of the use of any portable learning materials including portable radios, cell phones, audio cassettes, DVD players and audio CDs. Alexander (2004) defines mobile learning as a type of learning that has established the legitimacy of 'nomadic' learners. Nowadays, you can find a mobile phone easily in the market that is affordable for most of the people and incorporate high technology within itself. This can be considered as a valuable opportunity to save time for all people doing their affairs. The advent of mobile computing technology has evolved 
definition of M-learning. Using E-learning, if students have cell phone, they can learn anytime and anywhere, can use materials repeatedly, and can repeat the difficult part for them.

By the late 1970s, due to the eagerness shown from students for authentic and real world materials, Audio-lingual method gave its place to more communicative based methods of language teaching. Emergence of cognitive and sociolinguistic approaches, in the late 1980s and early 1990s, emphasized on the learner's engagement with authentic, meaningful and contextualized material and there was a thorough change in the use of technology in classroom. Today's mobile devices have the capacity for offering authentic language learning materials (for instance 3G/4G smartphones, tablet PC) and have been removing the lines between classroom and home. Moreover, the boundaries between the mobile devices and PCs are getting blurred (Yang, 2013). Mobile assisted language learning can be considered as a new subcategory of computer assisted language learning in line with the latest horizon report which highlighted educational potential of tablet computing and mobiles (Johnson et al., 2013; Johnson, Adams, \& Cummins, 2012).

One of the most applied applications of mobiles in language learning is short message services - SMS. According to Starovoit (2012), Text messaging or "texting" was only established and publicized in the mid-1990s. He claims that By 2009, 60 percent of the world's inhabitants already had contact with cell phone, and SMS was the second most shared way to employ the technology to communicate, after speaking person-to-person. Researches about how text messaging touch reading and writing initiated in the early 2000s. It was palpable that with an almost worldwide limit of 160 characters and a minute, stroppy keyboard that was frequently QWERTY-based, the mainstream of text message employers would likely lost precise use of language for speed. Texting language looks like speaking, with artless syntax, imperfect sentences and casual structure. As for English, the spelling conventions are fairly unlike Standard English, and the practice of abbreviations and phonetic spelling is regularly happening. In consort with the text message phenomenon, forewarnings of linguistic troubles that would be set free by text messaging ascended. Some of these were: "Texting uses new and nonstandard orthography, texting will inevitably erode children's ability to spell, punctuate, and capitalize correctly - an ability already thought to be poor, inevitably [to] transfer these new habits into the rest of their schoolwork" (Crystal, 2008, p.151).

However, Short messages service (SMS) can be of paramount help to English language instruction in particular and to languages in general. It can be damaging if not restricted and left to admit make up words, choppy lingo, sloppy spelling and grammatical errors to get a rapid and short message through (Starovoit, 2012). On the other hand, it can be a very worthy instrument to lift language skills and sub skills if used skillfully and written in correct English especially that it encompasses the main mass of people's communication. It can be reflected as an essential way to give speedy attention to words (Nation, 2001). Also, it is potential to emphasis on restricted amount of information, since too much amount of information can be puzzling and disheartening. In addition, they are inspiring for students, because they can learn the lessons delivered to them through SMS any time and in any location they like.

\section{Grammar in Foreign language classroom}

Grammar instruction should not be ignored. Efficient language use needs grammar knowledge since it will help language users combine words and sentences and turn them to meaningful utterances. High knowledge of grammar assists users construct accurate sentences in speaking and writing. High knowledge of grammar assists users construct unambiguous sentences and texts. Inappropriate use of structures does not create meaningful messages. Grammar instruction is to understand the mechanism of language. Appropriate grammar instruction helps learners use the language properly. Azar (2007) emphasizes the importance grammar instruction by stating that grammar teaching makes learners aware of the nature of language (that language is made of predictable patterns that make what we speak, read, listen and write understandable. Without grammar, there would have been only words or sounds, images, and body movements to convey and understand meaning. Grammar weaves the words to create the final product (Azar, 2007). To create accurate sentences, grammar knowledge is indispensable. One of the effective ways to incorporate grammar teaching is through SMS (short message service). SMS has been largely utilized in educational setting. However, they are mainly used for administrative purposes rather and not for instructional ones. Riordan and Traxler (2005), for instance, studied the role of curriculum modifications in favor of using the technology and pointed out that technology in general terms, significantly enhances students learning. Other studies have investigated the effectiveness of SMS as a learning strategy. Thornton and Houser (2001), for example, studied the role of SMS in 'pushing' learning resources to learners; the results revealed the effective role of SMS. They stated that in their study SMS technology helped learning in four different ways: first, SMS was effective for vocabulary learning; second, students like SMS; third, read their course content even without having the chance to reply to SMS appealed to the students; fourth, students open the messages as soon as they receive massages. Balasundaram and Ramadoss (2007) offers a strategy for the incorporation of SMS to testing through delivering short quizzes to students; they interacted with other students and teachers through reading and replying to the quizzes. In this study, the researcher aimed at exploring the teaching and learning of grammar to EFL students through the use of SMS. The following research questions have been posed by the researcher to achieve the goals of the study:

Q1: Does employment of SMS has any significant effects on Iranian upper-intermediate EFL learners' Grammar achievement?

Q2: Does employment of SMS has any significant effects on Iranian upper-intermediate EFL learners' autonomy? 


\section{REVIEW OF THE LITERATURE}

There is a mix of theories concerning grammar teaching. Some academics, for example Prabhu (1987), follow the prohibition of grammar learning. whereas other scholars accentuate the necessity to contain grammar instruction in CLT (for instance, Lightbown \& Spada, 1990; Nassaji, 2000; Spada \& Lightbown, 1993). The theory of acquisition versus learning, formulated by Krashen (1982, 1985), had a significant influence on the idea that concentrating solely on meaning is adequate for SLA. In his premise, Krashen suggests that there is a division between acquisition and learning. He considers that acquisition takes place naturally, on condition that learners obtain satisfactory comprehensible input, and that merely acquired knowledge can cause effortless communication. Similarly, Krashen's Monitor Hypothesis recommends that explicit form teaching simply functions as an instrument for observing learners' language. That is, learners pick up grammatical rules just to monitor the rightness of their language practice, which is additional to what has been acquired. Nevertheless, the backers of explicit grammar teaching maintain that it is insufficient to acquire a L2, if meaning is the only center. Long (1991) discriminates between focus on forms and focus on form. He outlines focus on forms as learning language structures, and focus on form as pushing students toward grammar in activities and tasks. In the last twenty years or so, some scholars have resumed the inquiry of form-focused instruction in CLT (for example, Celce-Murcia, 1991; Doughty \& Williams, 1998; Ellis, 1993; Long \& Crookes, 1992). The research on language accurateness of students in an immersion platform in Canada delivered vital suggestions that form focused teaching is desired (e.g. Harley \& Swain, 1984; Swain, 1985). These immersion learners received huge quantities of input and had ample opportunities of communication in the program for a period of time, but their speech still included grammatical mistakes. On account of withdrawing form-focused teaching, the learners' output showed lack of accuracy (Williams, 1995). Regardless of the undesirable reports about immersion platforms related to language acquisition, examinations specified the triumph of French immersion programs in Canada. The learners in the programs did better than those who educated French as a distinct theme in their total proficiency in French besides their awareness of the target language culture (Cummins \& Swain, 1986; Lessow-Hurley, 2009). Many educationalists misinterpret focus on form as instruction and learning of grammatical rules. Conversely, form-focused instruction does not signify offering rules to learners. A number of examinations (e.g. Doughty, 1991; Doughty \& Williams, 1998; Lightbown, 1991; Trahey\& White, 1993; White, 1991) have scrutinized the efficiency of focusing on form and designated that pupils with formfocused instruction outdone those deprived of teaching on the targeted forms. The outcomes of these researches are very imperative, as they back the role of form-focused instruction. Some instructors consider that form-focused teaching and communicative tasks, where the emphasis is on meaning, should be disconnected. Teachers think that leading students' attention toward grammar, as they are appealing to meaning, may have destructive outcomes (Lightbown, 1998). Nevertheless, some academics claim that form-focused instruction and communicative activities should be mutual. Students notice the target forms, and the forms become more outstanding, if students absorb them in context (Foto, 1994; Lightbown, 1998; Nassaji, 2000; Wang, 2009). Scholars argue that in line with the methodology of CLT, task based language teaching has been proposed.

Interests toward task-based language teaching (TBLT) has been highly expressed during the last 30 years. Interests in TBLT highlight the role of tasks in second and foreign language learning context. TBLT, which is extensively used in language acquisition classes (Ellis, 2003; Willis \& Willis, 2007), is expected to be known as an approach which has the power to compensate for the insufficiencies of communicative approach to language instruction and can be regarded as a natural expansion of CLT (Richards \& Rodgers, 2001). Techniques, principles, and process-/product-based incorporation of TBLT and its role in learning a second or foreign language has been one of the most studied areas of the field of second language learning during the last three decades (Klapper, 2003; McDonough, 1995; Szymanski, 2002). TBLT, in which students are provided with authentic, natural, and daily language related problems, is regarded as one of the most recent strands of applied linguistics. According to Nunan (2004), task-based language learning draws on the process of transformation and lets student fall into the real word language related activities. Based on TBLT principles, language is considered as an instrument for accomplishing tasks not simply as a subject. Simply put, language is viewed as an instrument to communicate and not an independent end.

Some previous studies have investigated the role of SMS in learning a new language. Kennedy and Levy (2008) and Levy and Kennedy (2005), for instance, report a strategy toward the incorporation of SMS to language classes. In these studies learners were provided with Italian vocabularies, expressions, and sample sentences as SMS messages through their cell phones. Both studies reported that the incorporation of SMS as an instructional tool was successful. Moreover, participants held a positive perception about the incorporation of SMS as a learning tool. Li and Erben (2007) found out that the use of SMS in language classes enhances language learners' intercultural awareness as well as critical thinking skills. Two other studies (Thornton \& Houser, 2005; Zhang et al., 2011) studied the role of SMS in enhancing language learners' vocabulary acquisition. The results were in line with previous studies (i.e. effectiveness of SMS). Lu (2008), recruited 30 senior high school students and through adopting a quasi-experimental design, divided them into two groups. The experimental group acquired English vocabulary through SMS, while the control group took the usual paper based materials. The findings revealed that experimental group participants achieved higher scores than control group participants in their vocabulary test. Zhang et al. (2011) in a similar study confirmed Lu (2008) findings. In another study Motallebzadeh and Ganjali (2011) studied the role of SMS in enhancing vocabulary knowledge and 
reading comprehension of 40 English learners. The findings showed that SMS utilization results in the development of vocabulary knowledge as well as reading comprehension skills.

\section{MeTHODOLOGY}

In this part, the researcher examined the participants, materials and procedure of this study.

\section{A. Participants and Setting}

Sixty upper-intermediate EFL learners studying English as their foreign language in Khorasan language institute were selected based on oxford placement test (OPT). The age of these participants ranged from 12 to 15 . Due to gender segregation in these language institutes only male learners were selected. These participants were randomly assigned into two groups: experimental and control. The institute has been working in this field for more than 10 years with the average of 300 students in each semester. Each semester finishes in 3 months. The girls and the boys are separated from each other in a way that Saturday and Wednesday are the days for girls and Sunday and Tuesday are the days for boys. Age range of students who register in this institute is from 4 to 25 where there are elementary, secondary, high school and university students. This study was performed in the spring semester in 2015. At the beginning of the study, the students who were chosen to participate in the study were given a consent form to fill and were asked to inform their parents about the study. The researcher also held a session with the educational supervisor of the institute, describing the procedure in detail for him. The educational supervisor agreed to help the researcher in the research process by providing her with a large class with enough chairs and a suitable time for the students.

\section{B. Instrumentation}

Different instruments have been used in this study for different purposes. The researcher used an oxford placement test at the beginning of the study in order to find the qualified participants for the study. Touchstone 2 (lowerintermediate) was used in order to teach experimental and control groups the grammatical structures. There was learner autonomy questionnaire developed by Kashefian (2002) which was used to estimate what were the effects of technology use on the students learning autonomy. Also, in order to investigate the study results about students' grammar learning, the researcher conducted two grammar tests as pretest and posttest based on Touchstone 2 book.

\section{Oxford placement test}

Proficiency tests refer to norm-referenced tests which are expected to "measure global language abilities" (Brown, 2005 , p. 2). One feature of a proficiency tests is that they need to provide scores which are normally distributed and lets relative interpretations of the test scores in terms of how each participant performed in relation to the performances of all other participants. The next feature of these tests is its structure; generally they are quite long and include a wide range of question content types and usually consist of a few subsections on rather general language skills including reading comprehension, listening comprehension, grammar, and writing. Moreover, the third characteristic of these tests is that they produce a wide range of scores so that interpretations of the differences among test takers be. Simply put, a proficiency test tends to measure participants' general language proficiency. OPT is divided into two sections: listening and grammar. The listening section consists of 100 items. It takes about ten minutes to take the listening test. Testtakers are required to select the correct alternative which they hear in short sentences from among two existing alternatives. Buck (2001) refer to these types of tests as phonemic discrimination tasks in which the test-takers are expected to distinguish two words which differ by one phoneme. The grammar section of OPT has 100 items. Test takers have 50 minutes to complete the test. They are required to fill in the blanks using one of the three options which follow the stem.

\section{Grammar test}

As the purpose of this study was improving learners' grammatical knowledge by the use of technology, the researcher made two different grammar tests as pre and posttests to limit the effect of test retest procedure. The test items were taken from the grammatical structures that are specified in Touchstone 2 syllabus. Both tests consist of 60 multiple-choice grammar items checking learners' understanding of different parts of the grammar. The learners had forty minutes to answer the questions. Both tests were pilot tested to check for their reliability and validity by the help of a group of 10 learners. The results of Cronbach alpha test should that the pretest and posttest enjoyed a reliability of 0.79 and 0.82 , respectively. Also, the validity test depicted 0.73 and 0.78 scores for the pretest and posttest.

\section{Learner Autonomy Questionnaire}

In order to measure EFL learners' autonomy, a questionnaire developed by Kashefian (2002, as cited in Hashemian \& Fadaei, 2013) was administered to the participants of both groups. The questionnaire consistes of two sections: The first section is related to the demographic information of the participants while the second section consists of 40 items on a 5-point Likert scale ranging from 1 (strongly agree) to 5 (strongly disagree) (see Appendix B). The items asked about the learner's attitude toward the role of the teacher/the learner, self-evaluation, learner's goal, planning, ability, progression, and mistakes throughout the process of learning, all of which make a contribution to the development of learner autonomy. In order to estimate the reliability of the questionnaire, the researcher asked 25 students to fill it and then used Cronbach Alpha to give the index of reliability. The Cronbach Alpha showed the value of 0.69 for the questionnaire that can be considered a good index for the reliability. The questionnaire was given to the students as a 
pretest before the beginning of the study. The aim was to estimate whether the students' autonomy toward stress pattern learning specially learning by the help of new technology was improved or not. Therefore, at the end of the study, the questionnaire was given to the both groups again and was analyzed by the help of SPSS package (version 19) in order to see if there has been any improvement or not.

\section{Procedure}

One hundred learners in the language institute participated in Oxford placement test. Among these learners, 60 individuals who scored between 80-100 were selected as lower intermediate learners. These learners were randomly assigned into two groups: an experimental group and a control group. All these learners took the OPD and their scores were documented. All of them were also asked to fill the autonomy questionnaire. For the purpose of this study, the researcher employed an SMS sending platform. With the help of this platform, the teachers were able to send SMS to all the learners in experimental group in the daily basis. The messages sent to the learners comprised of grammatical topics including reported speech and tenses, Simple and progressive past and simple and progressive present.

The learners in the experimental group received Educational SMS from the SMS service. The texts consist of 20 to 25 words explaining the grammatical rules. These SMS were sent to the learners in the daily basis for 8 weeks. The learners were required to memorize the grammatical rules and proactive them in the class with teacher. When the learners attended in the classroom, the teacher reviewed the rules with the learners and the learners were required to do some exercises on these topics.

The learners in the control group didn't receive SMS. They participated in the grammar class one a week and practiced the grammar lessons with the teachers. The teachers explained the grammar points to them one in each session and they were required to do the exercises related to these points.

At the end of the treatment, the learners in both groups underwent the posttest. Also beside that they were given the learners' autonomy questionnaire and were asked to fill it at home and give it back to the teacher.

In order to teach grammar to the learners the communicative language teaching approach was selected. The description of it is as follow:

Communicative: Task based Instruction in which students are provided with the task to be done in the classroom context presupposes that transacting tasks in this way would engage naturalistic learning system, make the existing interlanguage system be extended, and enhance learning. (Skehan, 1997). However, some previous studies revealed that small-group tasks may not have similar function (Seedhouse, 1999); these studies are contrast with the considerable evidence that explicit grammar instruction is likely to enhance learning.

Task-based + focus on form A communicative task, with incidental focus on form explicitly attracts students' attention to linguistic points as they come up incidentally during instruction whose principal focus is on meaning or communication (Long, 1991). They may be based on, for instance, error correction, noticing of salient forms in texts, or teacher or student-initiated attention to a grammatical point, originally: unplanned and brief (Long, 1991), but later largely planned and extended (Ellis, Basturkmen \& Loewen, 2002; Shak \& Gardner, 2008)

\section{Study Design}

This study enjoyed a quasi-experimental pretest posttest design. The learners were randomly assigned into two groups of experimental and control. The data were analyzed by the use of SPSS software version 21 . The researcher used independent sample t-test to analyze the data from pretest and posttest and questionnaire.

\section{RESULTS AND DiSCUSSION}

\section{A. Descriptive and Inferential Statistics for the First Research Question and Hypothesis}

The oxford placement test was conducted at the beginning of the study to check for the homogeneity of learners in the experimental and control groups. The results are provided below:

\begin{tabular}{|c|c|c|c|c|c|c|}
\hline \multicolumn{7}{|c|}{$\begin{array}{c}\text { TABLE } 1 \\
\text { OPT DESCRIPTIVE STATISTICS }\end{array}$} \\
\hline & $\mathrm{N}$ & Minimum & Maximum & Mean & Std. Deviation & Variance \\
\hline$\overline{\mathrm{Opt}}$ & 120 & 59.00 & 95.00 & 79.1083 & 8.58061 & 73.627 \\
\hline
\end{tabular}

The descriptive statistics for the control group's pretest scores is provided in Table 1 below:

TABLE 2.

\begin{tabular}{llllll} 
& \multicolumn{5}{c}{ CONTROL AND EXPERIMENTAL GROUP PRETEST'S SCORES } \\
& sms & $\mathrm{N}$ & Mean & Std. Deviation & Std. Error Mean \\
\hline \multirow{2}{*}{ Class } & 1.00 & 38 & 79.3684 & 2.11073 & .34241 \\
\cline { 2 - 6 } & 2.00 & 36 & 81.4722 & 3.31651 & .55275
\end{tabular}

According to Table 2, the number of students who took the test in class one is 38 and the mean of their scores is 79.36 with a standard deviation of 2.11 and the number of learners who took the test is in class two is 36 with 81.47 means. 
TABLE 3

INDEPENDENT SAMPLE T-TEST

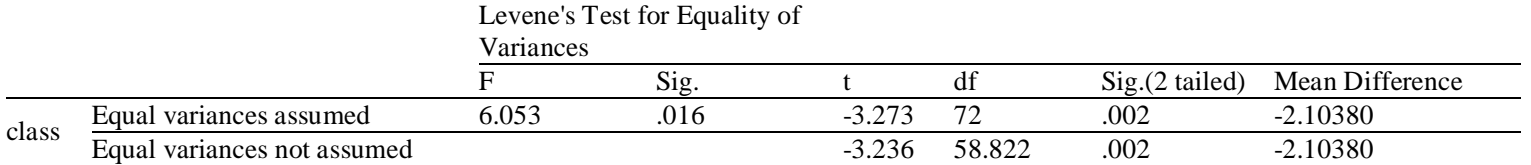

According to Table 3 and based on the independent sample t-test result, the difference between experimental and control groups' scores in the pretest is not significant $(\mathrm{p}<0.05)$ with $\mathrm{t}=3.27$ and sig $=.016$. So based on this result, the first null hypothesis is approved.

Then, the researcher examined whether the difference between control and experimental groups' posttests' results is significant or not. The experimental group has undergone treatment and the grammar were taught to them by the use of SMS while the control group has learned the grammar in the classroom.

The descriptive statistics for the control group's posttest scores is provided in Table 14 below:

TABLE 4

EXPERIMENTAL GROUP POSTTEST'S SCORES

\begin{tabular}{lllllll} 
& N & Minimum & Maximum & Mean & Std. Deviation & Variance \\
\hline Smspost & 38 & 76.00 & 87.00 & 81.3947 & 3.25111 & 10.570 \\
\hline Valid N (listwise) & 38 & & & &
\end{tabular}

The following table provides the post-test results for the experimental group.

TABLE 5

CONTROL GROUP POSTTEST'S SCORES

\begin{tabular}{lllllll} 
& $\mathrm{N}$ & Minimum & Maximum & Mean & Std. Deviation & Variance \\
\hline classpost & 38 & 76.00 & 84.00 & 79.3684 & 2.11073 & 4.455 \\
\hline Valid N (listwise) & 38 & & & &
\end{tabular}

In the following table, you can see both groups' statistics.

\begin{tabular}{llllll} 
& \multicolumn{5}{c}{ TABLE 6 } \\
& & \multicolumn{5}{c}{ GROUP STATISTICS } \\
\hline \multirow{2}{*}{ Class } & VAR00001 & $\mathrm{N}$ & Mean & Std. Deviation & Std. Error Mean \\
\cline { 2 - 6 } & 1.00 & 38 & 80.4737 & 2.23893 & .36320 \\
\hline
\end{tabular}

The following table provided the results of independent sample t-test.

TABLE 7

INDEPENDENT SAMPLE POSTTEST

\begin{tabular}{|c|c|c|c|c|c|c|c|}
\hline & & \multicolumn{6}{|c|}{$\begin{array}{l}\text { Levene's Test for Equality of } \\
\text { Variances }\end{array}$} \\
\hline & & $\mathrm{F}$ & Sig. & $\mathrm{t}$ & df & Sig. (2-tailed) & Mean Difference \\
\hline \multirow{2}{*}{ Class } & Equal variances assumed & 26.132 & .000 & -6.256 & 74 & .000 & -4.26316 \\
\hline & Equal variances not assumed & & & -6.256 & 62.371 & .000 & -4.26316 \\
\hline
\end{tabular}

As you can see in the above table, the difference between learners' scores in the posttests are significantly different $(\mathrm{p}<0.05)$.

B. Descriptive Statistics of the Autonomy Questionnaire.

To investigate the effect of podcasting on word stress pattern learning of Iranian EFL learners' autonomy, the Autonomy Questionnaire developed by Kashefian (2002, as cited in Hashemian \&Fadaei, 2013) (see Appendix C) was given to both control and experimental groups.

1. The results of the autonomy Questionnaire Pretest and Posttest in control group. Table 18 represents the descriptive statistics of the autonomy Questionnaire for Pre-Test and Post-Test in control group. In this table you can find the mean of students' scores for each question in the questionnaire. 
TABLE 8

DESCRIPTIVE STATISTICS OF THE PRE AND POSTTEST COLLABORATION QUESTIONNAIRE FOR CONTROL GROUP

\begin{tabular}{|c|c|c|}
\hline Number & Pretest Mean & Posttest Mean \\
\hline 1 & 1.64 & 2.21 \\
\hline 2 & 1.26 & 2.17 \\
\hline 3 & 1.84 & 2.03 \\
\hline 4 & 1.29 & 1.98 \\
\hline 5 & 2.42 & 2.21 \\
\hline 6 & 2.42 & 2.15 \\
\hline 7 & 2.36 & 2.24 \\
\hline 8 & 1.92 & 1.78 \\
\hline 9 & 1.43 & 1.62 \\
\hline 10 & 1.52 & 1.73 \\
\hline 11 & 1.46 & 1.25 \\
\hline 12 & 1.79 & 1.59 \\
\hline 13 & 2.58 & 1.72 \\
\hline 14 & 4.36 & 4.42 \\
\hline 15 & 3.75 & 4.89 \\
\hline 16 & 3.56 & 3.43 \\
\hline 17 & 3.78 & 4.12 \\
\hline 18 & 3.56 & 4.01 \\
\hline 19 & 3.98 & 3.91 \\
\hline 20 & 2.12 & 3.85 \\
\hline 21 & 0.99 & 3.00 \\
\hline 22 & 4.23 & 4.62 \\
\hline 23 & 3.98 & 4.72 \\
\hline 24 & 4.12 & 4.05 \\
\hline 25 & 3.85 & 3.65 \\
\hline 26 & 3.78 & 3.84 \\
\hline 27 & 3.76 & 3.99 \\
\hline 28 & 3.63 & 3.56 \\
\hline 29 & 3.99 & 4.48 \\
\hline 30 & 3.75 & 4.25 \\
\hline 31 & 4.24 & 4.72 \\
\hline 32 & 4.26 & 4.42 \\
\hline 33 & 3.36 & 3.53 \\
\hline 34 & 3.92 & 3.84 \\
\hline 35 & 2.89 & 3.96 \\
\hline 36 & 3.24 & 3.12 \\
\hline 37 & 1.58 & 2.43 \\
\hline 38 & 3.26 & 3.45 \\
\hline 39 & 1.76 & 2.85 \\
\hline 40 & 3.25 & 3.44 \\
\hline
\end{tabular}

As it is represented in the above table, you can find small differences between the pretest and posttest's means of learners' scores in the questionnaire

\section{The results of the autonomy Questionnaire Pretest and Posttest in experimental group.}

Table 19 represents the descriptive statistics of the autonomy Questionnaire for Pre-Test and Post-Test in experimental group. In this table you can find the means of students' scores for each question in the questionnaire. 
TABLE 9

DESCRIPTIVE STATISTICS OF THE PRE AND POSTTEST Collaboration QueSTIONNAIRE FOR EXPERIMENTAL GROUP

\begin{tabular}{|c|c|c|}
\hline Number & Pretest Mean & Posttest Mean \\
\hline 1 & 1.23 & 3.79 \\
\hline 2 & 1.56 & 4.41 \\
\hline 3 & 1.12 & 4.32 \\
\hline 4 & 1.01 & 3.74 \\
\hline 5 & 0.99 & 4.36 \\
\hline 6 & 1.78 & 3.63 \\
\hline 7 & 1.25 & 3.36 \\
\hline 8 & 1.36 & 3.54 \\
\hline 9 & 0.85 & 3.87 \\
\hline 10 & 1.25 & 3.48 \\
\hline 11 & 1.12 & 3.63 \\
\hline 12 & 1.54 & 2.42 \\
\hline 13 & 3.22 & 1.96 \\
\hline 14 & 4.12 & 2.78 \\
\hline 15 & 3.68 & 2.52 \\
\hline 16 & 3.72 & 4.46 \\
\hline 17 & 3.98 & 2.53 \\
\hline 18 & 3.56 & 1.72 \\
\hline 19 & 3.44 & 2.93 \\
\hline 20 & 2.78 & 1.23 \\
\hline 21 & 1.94 & 0.98 \\
\hline 22 & 4.12 & 1.75 \\
\hline 23 & 3.39 & 1.42 \\
\hline 24 & 4.18 & 2.53 \\
\hline 25 & 3.46 & 1.26 \\
\hline 26 & 3.62 & 1.78 \\
\hline 27 & 3.98 & 1.44 \\
\hline 28 & 3.53 & 1.56 \\
\hline 29 & 3.87 & 1.78 \\
\hline 30 & 3.75 & 1.43 \\
\hline 31 & 4.25 & 1.54 \\
\hline 32 & 4.63 & 2.45 \\
\hline 33 & 3.98 & 0.89 \\
\hline 34 & 3.52 & 2.23 \\
\hline 35 & 1.84 & 4.80 \\
\hline 36 & 3.65 & 1.68 \\
\hline 37 & 1.25 & 4.02 \\
\hline 38 & 3.18 & 1.78 \\
\hline 39 & 1.63 & 3.54 \\
\hline 40 & 3.26 & 1.68 \\
\hline
\end{tabular}

As Table 9 shows, the learners' means in Autonomy questionnaire has changed drastically from pretest to posttest.

\section{DISCUSSION}

The learning and teaching environments of the twenty first century is changing very fast due to unprecedented opportunities advancement of information and communication technologies have created for education. After around half a century of integrating computers into instruction, the rapid evolution of mobile devices is opening up a whole world of new learning experiences with technology. Mobile learning is a type of learning that takes place with the help of mobile devices (Kukulska-Hulme\& Shield, 2008) and simply means learning anywhere and at any time. While at the beginning, mobile learning focused on the role of mobile technologies and devices in education, in the recent years mobile learning is characterized with the mobility of the user and the informal learning that happens out of the classroom (Sharples, 2006). In this case, any portable and palmtop devices such as portable media player devices, tablets, and mobile phones contribute to mobile learning. Mobile phone and SMS are user friendly and people have been utilizing these tools for many years, almost since the primary generations of mobile phone so the learnability and utilization of technology is to a large extent greater. All in all, the utilization of SMS with mobile phones has very different instances of successful usage in language learning as in this study also reveals. Hence school administrators and policy makers should take into account SMS with mobile phones as another educational tool that has many latent advantages for education.

The findings of the present study revealed the effectiveness of SMS on EFL learners' grammar learning. The findings of the present study suggest that in the short term, there was considerable difference between learning vocabulary through SMS and learning it through using dictionary and learning vocabulary through SMS assisted the participants in the experimental group to develop their grammar knowledge in the post test. This suggests that using SMS helps to convey grammar structures into learners' long term memory. Since learners are used to spending a lot of time using their mobiles, so having grammatical structures on their mobiles might have assisted them to review the grammar points on a 
more regular basis. This can be claimed by the fact that in the posttest students of the experimental group progressed significantly and performed significantly better than the participants of the control group.

Significantly, better performance of the learners in the experimental group after the treatment was accredited to the advantages of using SMS to make a more enjoyable learning atmosphere by engaging students in authentic and real life way of learning in which they can cooperate to the benefits of each other. Experiencing something new with the help of technology which made it more modern and different from previous experiences, gave the learners a feel that learning can be much more fun and enjoyable in friendly and stress-free atmosphere where help and support have prominent importance.

As one of the chief drives of this study was to appraise the efficiency of SMS as a tool for grammar learning, the researcher, with the backing of the results of her research is willing to humbly present her creative technique in grammar learning, which can be considered a great help to the scientific society, specifically ELT community.

It can be concluded that in order to let learners put more emphasis and energy on studying new grammatical points, they need to shoulder the responsibility of the learning process. Furthermore, teaching methods need to be in a way that urges learners to review and study the instructed structures based on a more regular plan and take advantage of their object of interest (in the context of the present study, mobile phone).

\section{CONCLUSIONS}

According to the findings obtained from quantitative data, there was a statistically significant mean difference between the pretest and the posttest scores of the grammar test and autonomy questionnaire.

The obtained findings of the analysis of the results of the quantitative data revealed that SMS had a statistically significant effect on the increasing of the upper intermediate Iranian EFL learners' grammar knowledge, their effective learning of grammar as the cornerstone of language learning, their autonomy. Therefore, the findings provided enough strong evidence to reject first and second null hypothesis.

It is noteworthy to mention that along with SMS classroom learning of grammar itself as the treatment means of control group also had a statistically significant effect on the increasing the upper intermediate Iranian EFL learners' grammar knowledge, although it didn't improve students Autonomy.

Moreover, the findings showed some specific points about the effectiveness of SMS. The findings revealed that:

Working with authentic, daily life software of learning English- especially those used for vocabulary knowledge and involving in the process of discussing how to use it practically and effectively- attracted students' attention and affected their performance and achievement in course and created a positive attitude towards it.

Students, who are engaged in the process of learning, feel largely autonomous and take the responsibility for their own and other students' learning, practice with partners or in teams and share information and pay more attention to other learners' problems, achieve higher scores in the courses and adopt a positive attitude toward learning.

\section{A. Pedagogical Implications}

Based on the findings of this study following implications were obtained:

This study has investigated the effect of using SMS on Iranian upper-intermediate EFL learners' grammar knowledge, and autonomy. In order to investigate the effect of SMS on other skills and sub-skills such as speaking, listening, reading, writing and grammar more studies should be conducted.

Since SMS verified being successful and effective in it, probably it would be successful and effective in other learning areas. Therefore, as another pedagogical implication of this study, it is suggested to use SMS in other areas of learning separate from language learning.

Since the productivity of SMS as an educational tool was intertwined with different factors, as other pedagogical implications of this study, it is suggested that before its implementation in language learning curriculum, all the factors affecting its use such as internet connections, smartphones, students' social class, etc should be taken into consideration.

Moreover, being tangled in a new process of learning, learners would alter their outmoded habits of language learning such as rote learning for better learning practices. Furthermore, having the responsibility for learning and feeling autonomous make students independent in their process of learning and at the same time help them to work cooperatively, share information and care about each other's problems in a fun and enjoyable atmosphere.

Based on the findings of this study, it is inferred that experiencing learning with the help of an innovative technique such as SMS in a completely new environment, at first make students somehow feel anxious but as they go further, they feel that they are experiencing something modern and different and as a result, it develops a positive attitude towards learning.

It can be inferred from the findings of this study that one of the main elements in the process of language learning is having fun. Caring and supportive peers and teacher, nice and lovely environment and feeling of autonomy and responsibility all increases the students' achievements significantly, creates a positive attitude towards learning, and makes the learning experience fun, enjoyable, and memorable for the learners.

Replication of this study on different proficiency levels, different age samples, other language skills, and in other learning situations is speculated to present more detailed and more thorough findings. These studies would better reveal 
if SMS is effective for a wider range of age groups, proficiency levels, other skills, and in other educational contexts or not.

\section{B. Suggestions for Further Research}

Based on the findings of this study and literature review following suggestions can be offered:

\section{Suggestions for teachers.}

Bearing in mind the trouble of managerial and controlling tasks in classrooms- particularly for lower age groups- it is desired to use SMS in a class with large number of students. In addition, the number of students in the classes can be increased provided that they are following teachers' instructions. Also the teacher some have a specifically developed language syllabus for each group and each class of students.

As Iranian learners are used to learning in a traditional educational system with great dependence on the instructor as the foremost foundation of organizing the knowledge, decision maker, problem solver, and almost the authority in the classroom, at the beginning of a course it is kind of difficult for the learners to accept the fact that they can also be the authority and decision maker of their own learning. Furthermore, it is tough for them to succeed in trusting their peer learners and themselves as knowledge source to deliver information and share it with others. Therefore, as a matter of fact, at the beginning of the way, the learners have problems involving in the course and sometimes so what seems to be necessary is teachers' patience and clarity in the whole process of learning.

The teacher should give the students assignments that the purpose and aims of their course are determined. Students can be asked to practice collaborative learning in their traditional classrooms before being mainstreamed in the new environment. Teachers can hold frequent sessions with students in order to help them and provide them with the necessary regulation.

Since the students who participated in the study, experienced their first experience of learning a language in a completely technological environment which is far from their old sanctuary, it is recommended that they are used as knowledgeable people in this field who can help the other students in the process.

Using SMS is only one manifestation of using new and interactive technologies in the classroom, however, the teachers, students and researchers are recommended to use other different technological innovations such as podcasting, wikis, blogs, second life, etc. to improve the process of language learning.

2. Suggestions for students. Observing and monitoring the process of this study, the researcher suggests that the students should be willing to experience something new in their process of learning; otherwise the efforts will not produce desired results. Some students are naturally unwilling to change and experience something new and some of them believe that the old ways of learning are the best. While engaging in group activities in technology-based learning, one of the vital elements is that each and every group member should be responsible for others' improvement, in terms of their learning and erudition. It is should not be neglected that new technologies can bring learners much closer to each other and so students should use this opportunity not only to improve their learning skills but also to improve their social skills.

3. Suggestions for textbook writers. According to the results of this study and other studies in applying new technologies in the language learning process, it is suggested that the lack of attention and place for new technologies in modern language learning textbooks should be taken into consideration. It is revealed that using SMS as an innovative tool in language learning can be very amusing and operational if it is fully recognized. English textbooks used in schools in Iran include old texts and the educational methods underlying them are also very old (going back to the grammar translation method). Recently, there has been some emphasis from the ministry of education to incorporate new technologies in the learning process. However, it seems that achieving to this goal needs a lot of patience and will take ages. But researches such as the current paper can help the teachers, learners, stakeholder and everybody who is responsible in this topic to move faster along the line of progress.

\section{REFERENCES}

[1] Azar, B. (2007). Grammar-Based Teaching: A Practitioner's Perspective. TESL-EJ. 11(2). 1-12 Retrieved September 12, 2012 from <http://www.tesl-ej.org/ej42/a1.pdf >.

[2] Alexander, B. (2004). Going Nomadic: Mobile Learning in Higher Education. Educause Review, 39 (5), 28-35.

[3] Balasundaram, S. R., \& Ramadoss, B. (2007). SMS for question-answering in the m-Learning scenario. Journal of Computer Science, 3 (2), 119-121. Retrieved December 10, 2007, from http://www.scipub.org/fulltext/jcs/jcs32119-121.pdf.

[4] Bax, S. (2003). CALL--past, present and future. System, 31(1), 13-28. http://dx.doi.org/10.1016/S0346-251X(02)00071-4.

[5] Chinnery, G. M. (2006). Emerging technologies, going to the MALL: Mobile Assisted Language Learning. Language Learning \& Technology, 10, 9-16.

[6] Dickins, P., \& Woods, E. (1988). Some criteria for the development of communicative grammar tasks. TESOL Quarterly, 22, 623-646.

[7] Ellis, R. (2003). Task-based language learning and teaching. Oxford: Oxford University Press.

[8] Ellis, R. (2006). Current issues in the teaching of grammar: An SLA perspective. TESOL Quarterly, 40(1), 83-107.

[9] Ellis, R. (2008). "The Place of Grammar Instruction in the Second/Foreign Language Curriculum". In E. Hinkel and S. Fotos (eds.), New Perspectives on Grammar Teaching in Second Language Classrooms. New York: Routledge.

[10] Johnson, L., Adams Becker, S., Cummins, M., Estrada, V., Freeman, A., \& Ludgate, H. (2013). NMC Horizon Report: 2013 Higher Education Edition. Retrieved from http://www.cdc.qc.ca/pdf/2013-Horizon-Report-creative-commons-copy.pdf. 
[11] Johnson, L., Adams, S., \& Cummins, M. (2012). The NMC horizon report: 2012 higher education edition. Retrieved from http://akgul.bilkent.edu.tr/nmc/2012-Horizon-Report-HE.pdf.

[12] Kennedy, C., \& Levy, M. (2008). L'italiano al telefonino: Using SMS to support beginners' language learning. ReCALL, 20(3), 315-330. http://dx.doi.org/10.1017/S0958344008000530.

[13] Kennedy, G., Krause, K., Churchward, A., Judd, T., \& Gray, K. (2006). First year students' experiences with technology: Are they really Digital Natives? Internal report. The University of Melbourne. Retrieved December 10, 2007 from http://www.bmu.unimelb.edu.au/research/munatives/natives_report2006.pdf.

[14] Klopfer, E, Squire, K and Jenkins, H. (2002). Environmental Detectives: PDAs as a window into a virtual simulated world. Proceedings of IEEE International Workshop on Wireless and Mobile Technologies in Education. Vaxjo, Sweden: IEEE Computer Society, 95-98

[15] Levy, M. (1997). Computer-assisted language learning: Context and conceptualization. London: Oxford University Press.

[16] Levy, M., \& Kennedy, C. (2005). Learning Italian via mobile SMS. In A. Kukulska-Hulme, \& J. Traxler (Eds.), Mobile learning: A handbook for educators and trainers (pp. 76-83). London: Taylor and Francis.

[17] Lightbown, P., \& Spada, N. (1990). Focus on form and corrective feedback in communicative language teaching: Effects on second language learning. Studies in Second Language Acquisition, 12, 429-446.

[18] Long, M. (1983). Does second language instruction make a difference? A review of research. TESOL Quarterly, 17, 359-382.

[19] Long, M. (1988). Instructed interlanguage development. In L. Beebe (Ed.), Issues in second language acquisition: Multiple perspectives. New York: Newbury House.

[20] Long, M., \& Crookes, G. (1992). Three approaches to task-based syllabus design. TESOL Quarterly 26, $27-56$.

[21] Lu, M. (2008). Effectiveness of vocabulary learning via mobile phone. Journal of Computer Assisted Learning, 24(6), 515-525. http://dx.doi.org/10.1111/j.1365-2729.2008.00289.x.

[22] Lu, J, Chun-Sheng, Chang, L. \& Yao, J.E. (2003). Technology Acceptance Model of Wireless Internet. Internet Research: Electronic Networks Application \& Policy, 13(3), 206-222

[23] Motallebzadeh, K., \&Ganjali, R. (2011). SMS: Tool for L2 Vocabulary Retention and Reading Comprehension Ability. Journal of Language Teaching and Research, 2(5), 1111-1115. http://dx.doi.org/10.4304/j1tr.2.5.1111-1115.

[24] Nassaji, H. (2000). Towards integrating form-focused instruction and communicative interaction in L2 classroom: Some pedagogical possibilities. The Modern Language Journal, 84(2), 241-250.

[25] Prensky, M. (2005). Adopt and adapt: Shaping tech for the classroom. Retrieved October 15, 2007, from http://www.edutopia.org/node/1423/print.

[26] Richards, J. C. (2008). “Accuracy and Fluency Revisited”. In E. Hinkel and S. Fotos (eds.), New Perspectives on Grammar Teaching in Second Language Classrooms. New York: Routledge.

[27] Sharples, M. (ed.) (2006). Big issues in mobile learning. Report of a workshop by the Kaleidoscope Network of Excellence Mobile Learning Initiative. UK: University of Nottingham.

[28] Shield L. \&Kukulska-Hulme A. (eds.). (2008). Special edition of ReCALL on Mobile Assisted Language Learning: http://www.eurocalllanguages.org/recall/rcontents.html\#sep08 [December, 2012].

[29] Skehan, P. (1998). A cognitive approach to language learning. Oxford: Oxford University Press.

[30] Skehan, P. (2007). Task research and language teaching: Reciprocal relationships. In S. Fotos, and H. Nassaji (Eds.): Formfocused instruction and teacher education: Studies in honor of Rod Ellis. (pp. 28-48). Oxford: Oxford University Press.

[31] Skehan, P. (2014). The context for researching a processing perspective on task performance. In P. Skehan (Ed.), Processing perspectives on task performance (pp. 1-26). Philadelphia/Amsterdam: John Benjamins. http:// dx.doi.org/10.1075/tblt.5.

[32] Skehan P. \& Foster, P. (1999). The influence of task structure and processing conditions on narrative retellings. Language Learning, 49(1), 93-120.

[33] Starovoit,V. (2012) How does Text Messaging Affect the Ability to Write and Speak in English? How culture and society languages speak English www.ehow.com/about_6501816_text-ability-write-speak-english_.html.

[34] Spada, N., \&Lightbown, P. M. (1993). Instruction and the development of questions in the L2 classroom. Studies in Second Language Acquisition, 14, 205-221.

[35] Swain, M. (1985). Communicative competence: Some roles of comprehensible input and comprehensible output in its development. In S. Gass\& C. Madden (Eds.), Input in second language acquisition, (pp. 235-256). New York: Newbury House.

[36] Swain, M., \&Lapkin, S. (1990). Aspects of the sociolinguistic performance of early and late French immersion students. In R. Scarcella, E. Andersen, \& S. Krashen (Eds.), Developing communicative competence in L2 (pp. 41-54). Boston, MA: Heinle \& Heinle Publishers.

[37] Thornton, P., \& Houser, C. (2005). Using mobile phones in English education in Japan. Journal of Computer Assisted Learning, 21(3), 217-228. http://dx.doi.org/10.1111/j.1365-2729.2005.00129.x.

[38] Traxler, J \& Riordan, B. (2003). Evaluating the effectiveness of retention strategies using SMS, WAP and WWW student support. Proceedings of 4th Annual Conference. Galway, Ireland: LTSN Centre for Information and Computer Science, 54-55

[39] Williams, J. (1995). Focus on form in communicative language teaching: Research findings and the classroom teacher. TESOL Journal, 4(4), 12-16.

[40] White, L. (1991). Adverb placement in second language acquisition: Some effects ofpositive and negative evidence in the classroom. Second Language Research, 7, 133-161.

[41] White, L., Spada, N., Lightbown, P., \&Ranta, P. (1991). Input enhancement and L2 question formation. Applied Linguistics, 12, 416-432.

[42] Wang, S., \& Heffernan, N. (2009). Mobile 2.0 and Mobile Language Learning. In M. Thomas (Ed.), Handbook of Research on Web 2.0 and Second Language Learning (pp. 472-490): IGI Global.

[43] Zhang, H., Song, W., \& Burston, J. (2011). Reexamining the effectiveness of vocabulary learning via mobile phones. TOJET, $10(3), 25-38$. 
Mohamad Reza Farangi is a $\mathrm{PhD}$ candidate in applied linguistics at Shiraz University, Shiraz, Iran. He has published several papers in national and international journals and participated in various conferences in the field. His field of interest is teaching methodologies, discourse studies and CALL.

Jamileh Kamyab holds an MA in Teaching English as a foreign language from Islamic Azad University. She has published several papers in national and international journals. Her field of interest is CALL.

Majid Izanlu holds an MA in applied linguistics from Kharazmi University, Tehran, Iran. He has published several papers in national and international journals and participated in various conferences in the field. His field of interest is teaching methodologies, language testing and CALL.

Nazanin Ghodrat is a lecturer on English translation at Payame noor University of Sistan and Baluchestan. She holds an MA in English translation from Kharazmi University, Tehran. Iran. She has published several articles in language and translation studies in several journals. 